\title{
PENGGUNAAN METODE PROBLEM SOLVING DALAM PEMBELAJARAN DEBAT DI KELAS X SMA NEGERI 1 SAWAN
}

\author{
Ni L. Eka Sumiarti ${ }^{1}$, I B. Putrayasa ${ }^{2}$, I W. Wendra ${ }^{3}$ \\ Jurusan Pendidikan Bahasa dan Sastra Indonesia, Fakultas Bahasa \\ dan Seni Universitas Pendidikan Ganesha \\ Singaraja, Indonesia \\ e-mail: \{Sumiarti_eka@yahoo.co.id, ibputra@gmail.com, \\ wayan_wendra@yahoo.com\}
}

\begin{abstract}
ABSTRAK
Penelitian ini bertujuan untuk mendeskripsikan (1) penggunaan metode problem solving oleh guru bahasa Indonesia dalam pembelajaran debat di kelas $X$ (2) respons siswa terhadap penggunaan metode problem solving oleh guru bahasa Indonesia dalam pembelajaran debat di kelas $X$ (3) kendala guru yang datang dari siswa dalam penggunaan metode problem solving pada pembelajaran debat di kelas X SMA Negeri 1 Sawan. Penelitian ini menggunakan rancangan penelitian deskriptif kualitatif. Subjek penelitian ini adalah guru dan siswa. Metode pengumpulan data yang digunakan adalah metode observasi dan metode wawancara. Data dalam penelitian ini dianalisis secara deskriptif kualitatif. Hasil penelitian ini ialah (1) penggunaan metode problem solving dalam pembelajaran debat telah memenuhi prosedur, yaitu pada awal pembelajaran guru mampu mengarahkan siswa, pada inti pembelajaran siswa mampu mengikuti debat dengan maksimal, dan pada akhir pembelajaran siswa memperoleh gambaran mengenai metode problem solving dalam debat. (2) respons siswa sebagian besar positif, yakni menyenangi penuh metode problem solving, namun sebagian kecil kurang menyenangi metode problem solving. (3) kendala guru adalah dari segi siswa dan fasilitas. Simpulan penelitian ini adalah (1) penggunaan metode problem solving telah efektif dan sesuai prosedur. (2) respons siswa sebagian besar positif. (3) kendala yang ditemukan oleh guru adalah dari segi siswa dan fasilitas sekolah yang sangat terbatas.
\end{abstract}

Kata Kunci: debat, pembelajaran, problem solving.

\section{Abstract}

This study aimed for describing:1) the use of problem solving method by Indonesian teacher in debate in $10^{\text {th }}$ grade students 2) students response towards the use of problem solving method by Indonesian teacher in debate in $10^{\text {th }}$ grade students, 3) the teachers obstacle about the use of problem solving method by Indonesian teacher in debate in $10^{\text {th }}$ grade students of SMA Negeri 1 Sawan. This study used descriptive qualitative design. The subjects of this study are the teacher and the students. This study used several methods such as observation and interview. The data was analyzed by using descriptive qualitative. The result showed that: 1) the use of problem solving method has fulfilled the procedure, in the beginning the teacher can guide the students, in the middle of the learning process the students can follow the debating activity maximally, in the end the students knew about the problem solving method in debate, 2) the students 
response are dominantly positive towards problem solving method, 3) the teacher's obstacle are students and facilities. The conclusions of this study are: 1) the use of problem solving method was effective and fulfilled the procedure, 2) 2) the students response are dominantly positive, 3 ) the teacher's obstacle are the students and the facilities in the school.

Keyword: debate, lesson, problem solving

\section{PENDAHULUAN}

Pendidikan merupakan usaha
sadar dan terencana untuk mewujudkan proses pembelajaran. Menurut Martha (2009: 22) pedidikan tidak lain adalah kegiatan intelektual yang membangkitkan kesadaran intelek pada diri individu. Proses pendidikan tentu tidak dapat dipisahkan dari kegiatan belajar, kegiatan belajar tidak dapat luput dari peran guru (pendidik). Pada era globalisasi, profesi guru bermakna strategis, karena penyandangnya mengemban tugas sejati bagi proses kemanusiaan, pemanusiaan, pencerdasan, pembudayaan, dan pembangun karakter bangsa (Wendra, 2015: 1). Hal itu berarti guru adalah subjek dalam intsitusi pendidikan sekaligus berperan penting dalam mencapai tujuan pendidikan. Sebagai seseorang yang berdiri paling depan dalam dunia pendidikan, guru tentu harus memahami situasi dan kondisi saat menjalankan perannya. Dalam kegiatan belajar-mengajar, salah satu yang dapat melatih keterampilan berpikir siswa adalah kegiatan diskusi. Ada tiga belas jenis diskusi, salah satunya adalah debat. Debat adalah kegiatan beradu argumentasi dalam membahas suatu masalah, guna mencapai solusi atas permasalahan tersebut.

Penelitian tentang debat pernah dilakukan oleh peneliti lain yang bernama Ni Putu Ayu Nita Lestariani pada tahun 2014, ia melakukan penelitian dengan judul "Kesantunan Bahasa Siswa Kelas X SMA Negeri 1 Selemadeg dalam Debat pada Pembelajaran Berbicara". Hasil penelitian dan pembahasannya adalah kesantunan bahasa siswa dalam debat, memfokuskan pada bahasa atau tuturan yang diucapkan siswa dalam debat. Penelitian tersebut hanya meneliti aspek siswa, yaitu bahasa yang digunakan siswa ketika berdebat. Semestinya penelitian tersebut tidak hanya meneliti aspek siswa, tetapi juga aspek guru. Salah satu aspek guru yang bisa diteliti adalah metode pembelajaran yang digunakan dalam debat.

Pisau bedah yang digunakan dalam penelitian ini adalah teori debat yang disampaikan oleh Tarigan (2008: 2), bahwa debat adalah suatu argumen untuk menentukan baik tidaknya suatu usul tertentu yang didukung oleh satu pihak yang disebut pendukung atau afirmatif, dan ditolak, disangkal oleh pihak lain yang disebut penyangkal atau negatif. Teori lain yang digunakan, yaitu teori tentang keterampilan membuka pelajaran yang disampaikan oleh Supriatna dan Wahyupurnomo (dalam Jurnal Keterampilan Guru dalam Membuka dan Mneutup Pelajaran Pendidikan Jasmani Olahraga dan Kesehatan di SMAN se-Kota Pontianak, 2015:2), bahwa keterampilan membuka pelajaran kegiatan dan pernyataan guru yang dilakukan pada pertama 
kali kegiatan pembelajaran dilaksanakan dengan tujuan untuk mencapai suasana siap mental dan menimbulkan perhatian siswa agar terpusat pada hal-hal yang akan dipelajari. Selain itu, teori tentang manfaat metode problem solving untuk siswa yang disampaikan oleh Dhajiri (1985: 133), bahwa manfaat metode problem solving adalah mengembangkan keterampilan berpikir seseorang. Selanjutnya, Jonassen (dalam Yaumi, 2012: 82), bahwa metode problem solving adalah jenis pelajaran terpenting yang bisa dipelajari di sekolah dan di kehidupan nyata. Selain itu, teori tentang pengelolaan kelas yang disampaikan oleh Sunhadi (dalam Jurnal Konsep Manajemen Kelas dan Implikasinya dalam Pembelajaran, 2014: 31). Selanjutnya, teori tentang motivasi belajar yang disampaikan oleh Handhika (dalam Jurnal Efektivitas Media Pembelajaran IM3 Ditinjau dari Motivasi Belajar, 2012: 2), bahwa motivasi dapat menumbuhkan gairah, merasa senang dan semangat untuk belajar. Teori lain yang digunakan yaitu tentang manfaat metode problem solving yang disampaikan oleh Dhajiri (1985: 133), bahwa manfaat metode problem solving adalah mengembangkan kemampuan berpikir para siswa, metode problem solving dapat menambah pengetahuan siswa, karena siswa dituntut dapat mengidentifikasi masalah dan mencari alternatif masalah yang dihadapi. Selanjutnya, teori tentang kendala pembelajaran yang disampaikan oleh Hadisoeparto (2003: 117) bahwa kendala yang disebabkan oleh siswa bisa terjadi apabila dalam proses belajar-mengajar siswa tidak berantusias dan merasa kurang termotivasi mengikuti pembelajaran yang dilaksanakan oleh guru. Metode pembelajaran yang digunakan dalam debat dibedah menggunakan teori-teori yang rekevan dengan data yang diperoleh peneliti. Metode pembelajaran merupakan aspek yang penting dalam kegiatan belajar. Karena dapat melatih keterampilan siswa dan berpengaruh terhadap motivasi belajar siswa. salah satu metode pembelajaran yang dapat melatih keterampilan berpikir siswa adalah metode problem solving. Metode problem solving digunakan dalam pembelajaran debat oleh guru Bahasa Indonesia kelas X SMA Negeri 1 Sawan yang bernama Ketut Darmayani Bukian, S.Pd. Bagi guru metode problem solving dapat melatih keterampilan berpikir kritis siswa, karena tidak sekadar metode mengajar tetapi juga merupakan metode berpikir.

Dengan menggunakan metode problem solving, siswa tidak hanya terampil berargumentasi, namun juga terampil mencari titik penyelesaian masalah. Dengan demikian, tidak akan terjadi dendam pada kedua kelompok serta tidak akan ada pertanyaan dalam diri siswa karena permasalahan telah berhasil dipecahkan dan diberikan jalan keluar oleh siswa berkat peran guru di dalamnya. Jadi, penelitian ini bertujuan mendeskripsikan tiga hal, yiatu (1) penggunaan metode problem solving oleh guru Bahasa Indonesia dalam pembelajaran debat di kelas X SMA Negeri 1 Sawan, (2) respons siswa terhadap penggunaan metode problem solving oleh guru Bahasa Indonesia dalam pembelajaran debat di kelas X SMA Negeri 1 Sawan, (3) kendala guru dalam menggunakan metode problem solving pada pembelajaran 
debat di kelas X SMA Negeri 1 Sawan.

Penelitian ini dapat memberikan manfaat yang bersifat teoretis dan praktis kepada berbagai pihak. Secara teoretis, hasil penelitian ini diharapkan mampu memberikan sumbangan konseptual yang edukatif pada pendidikan bahasa, khususnya pada penggunaan metode problem solving dalam pembelajaran debat, dapat memberikan informasi sekaligus sumbangan untuk memperluas teori tentang metode problem solving dalam pembelajaran debat. Secara praktis, penelitian ini bermanfaat bagi guru atau pengajar Bahasa dan Sastra Indonesia, termasuk bagi peneliti sendiri sebagai calon guru Bahasa dan Sastra Indonesia, hasil penelitian ini diharapkan dapat memperkaya wawasan pengajar dalam pembelajaran debat. Bagi siswa, penelitian ini dapat menjadi pedoman dalam pembelajaran Bahasa Indonesia, khususnya pembelajaran debat. Bagi sekolah, hasil penelitian ini dapat dijadikan informasi tindak lanjut terhadap metode pembelajaran di kelas agar lebih inovatif dan kreatif, yang dilaksanakan tidak hanya oleh guru Bahasa Indonesia tetapi guru mata pelajaran yang lain. Bagi peneliti lain, hasil penelitian ini dapat dimanfaatkan sebagai bahan perbandingan atau referensi ketika melakukan penelitian sejenis.

\section{METODE PENELITIAN}

Rancangan penelitian yang digunakan dalam penelitian ini adalah rancangan deskriptif kualitatif. Penelitian ini diharapkan mampu mendeskripsikan mampu mendeskripsikan penggunaan metode problem solving oleh guru
Bahasa Indonesia dalam pembelajaran debat di kelas X SMA Negeri 1 Sawan.

Subjek penelitian ini adalah guru bahasa Indonesia kelas $X$, yaitu Ketut Darmayani Bukian, S.Pd dan siswa kelas X MIA 1. Penentuan subjek penelitian ini menggunakan teknik simple random sampling, sedangkan objek penelitian ini ada tiga, yaitu penggunaan metode problem solving oleh guru bahasa Indonesia dalam pembelajaran debat, respons siswa terhadap penggunaan metode problem solving oleh guru Bahasa Indonesia dalam pembelajaran debat, dan kendala guru dalam menggunakan metode problem solving pada pembelajaran debat.

Tujuan utama penelitian adalah mendapatkan data sesuai dengan masalah penelitian. Metode pengumpulan data yang benar akan menghasilkan data yang memiliki kredibilitas tinggi (Sujarweni, 2014: 31). Oleh karena itu, tahap pengumpulan data tidak boleh salah dan harus dilakukan dengan cermat sesuai prosedur serta ciri-ciri penelitian. Dalam penelitian ini, peneliti menggunakan metode observasi tanpa partisipasi, instrumen yang digunakan adalah lembar observasi dan alat perekam. Peneliti juga menggunakan metode wawancara, instrumen yang digunakan adalah pedoman wawancara terstruktur.

Selanjutnya, data dalam penelitian ini dianalisis secara deskriptif kualitatif dengan menggunakan prosedur model analisis Miles dan Faisal (dalam Sujarweni, 2014: 34), terdiri atas reduksi data, penyajian data, serta penyimpulan dan verifikasi. Hasil akhir nanti diperoleh informasi mengenai penggunan metode 
problem solving oleh guru bahasa Indonesia dalam pembelajaran debat di kelas X SMA Negeri 1 Sawan.

\section{HASIL DAN PEMBAHASAN}

Hasil penelitian ini meliputi (1) penggunaan metode problem solving dalam pembelajaran debat, (2) respons siswa terhadap penggunaan metode problem solving dalam pembelajaran debat, (3) kendala guru dalam menggunakan metode problem solving pada pembelajaran debat. Pertama, data mengenai penggunaan metode problem solving oleh guru Bahasa Indonesia dalam pembelajaran debat di kelas $X$ SMA Negeri 1 Sawan diperoleh menggunakan metode observasi. Kedua, data mengenai respons siswa terhadap penggunaan metode problem solving dalam pembelajaran debat di kelas X SMA Negeri 1 Sawan diperoleh menggunakan metode wawancara. Ketiga, data mengenai kendala guru dalam menggunakan metode problem solving pada pembelajaran debat di kelas X SMA Negeri 1 Sawan diperoleh menggunakan metode wawancara.

Hasil penelitian yang diperoleh akan dibahas satu per satu sebagai berikut. Berbicara tentang debat tentu tidak asing lagi di telinga masyarakat, terutama di kalangan pelajar. Di dalam hidup manusia tidak akan bisa menghindari pertentangan dan silang pendapat, baik dengan keluarga, teman, dan lain-lain. Jika telah terjadi silang pendapat, tentu terjadi perdebatan. Seseorang harus pandai berdebat dengan baik dan bijaksana agar tidak terjadi debat kusir, yang pada akhirnya akan menambah permasalahan. Debat merupakan salah satu kegiatan diskusi untuk bertukar pikiran dalam memecahkan permasalahan. Senada dengan hal tersebut, Tarigan (2008: 92) menyatakan bahwa debat merupakan suatu argumen untuk menentukan baik tidaknya suatu usul tertentu yang didukung oleh satu pihak yang disebut pendukung atau afirmatif, dan ditolak, disangkal oleh pihak lain yang disebut penyangkal atau negatif. Berdasarkan pendapat tersebut, debat merupakan kegiatan yang dekat dengan kehidupan manusia, terutama di lingkungan pendidikan, seperti halnya di kelas X MIA 1 SMA Negeri 1 Sawan. Penggunaan metode problem solving dalam pembelajaran debat di kelas tersebut telah berlangsung efektif dan kondusif, serta memenuhi prosedur. Pada awal pembelajaran guru telah mampu menggiring siswa mengikuti pembelajaran debat dengan baik. Sebelum menukik pada inti pembelajaran, guru terlebih dahulu menggali pemahaman siswa tentang materi yang telah dibahas. Hal tersebut terbukti ketika guru bertanya tentang, "apa itu debat?" kepada seluruh siswa. Mendengar pertanyaan tersebut, siswa yang bernama Kadek Yuliani mengacungkan tangan. Berikut kutipan jawaban yang disampaikan oleh Kadek Yuliani.

Yuliani: "Debat itu persilangan pendapat bu, maksudnya orang yang berbeda pendapat itu bertemu."

Mencermati kutipan jawaban yang disampaikan oleh siswa tersebut, guru telah mampu menggiring siswa agar memiliki bayangan terhadap pelaksanaan debat, sehingga siswa mampu mengikuti pembelajaran debat dengan baik. Eksplorasi yang dilakukan guru memang harus 
menggiring siswa agar fokus pada pembelajaran yang akan dilaksanakan. Berdasarkan kegiatan awal tersebut, guru telah mampu menggiring siswa agar mengikuti pembelajaran debat dengan baik. Dalam hal tersebut terbukti bahwa guru telah memiliki keterampilan dasar mengajar dan pengelolaan pembelajaran. Seorang guru memang diupayakan agar memiliki kemampuan dasar mengajar agar mampu mengarahkan siswa pada gambaran pembelajaran yang akan dilaksanakan, salah satunya adalah membuka pembelajaran. Senada dengan hal itu, Supriatna dan Wahyupurnomo (dalam Jurnal Keterampilan Guru dalam Membuka dan Menutup Pelajaran Pendidikan Jasmani Olahraga dan Kesehatan di SMAN se-Kota Pontianak, 2015: 2) menyatakan bahwa keterampilan membuka pelajaran merupakan kegiatan dan pernyataan guru yang dilakukan pada pertama kali kegiatan pembelajaran dilaksanakan dengan tujuan untuk mencapai suasana siap mental dan menimbulkan perhatian siswa agar terpusat pada hal-hal yang akan dipelajari.

Pada kegiatan inti pembelajaran, siswa telah mampu mengikuti pembelajaran debat dengan maksimal, berdiskusi dengan baik, saling berargumentasi dengan tertib, dan guru berperan aktif ketika menyatukan persepsi siswa untuk memperoleh alternatif masalah, sehingga tidak terjadi debat kusir. Hal tersebut terbukti ketika siswa mampu menyampaikan argumentasi dengan baik dalam berdebat, seperti argumentasi yang disampaikan oleh siswa yang bernama Kadek Prima Budiadnyana. la menyampaikan argumentasi pro mengenai "Keberadaan Rokok
Berpengaruh Baik terhadap Perekonomian Negara Indonesia." Berikut kutipan argumentasi yang disampaikan oleh Kadek Prima Budiadnyana.

Prima (pro 2): "Kita tidak setuju dengan pandangan tim kontra. Rokok memang membuat kecanduan perokok tapi kan tidak salah rokok itu, itu salah perokoknya. Perokok seharusnya mampu mengatur berapa rokok yang dihisap dalam sehari. Dengan begitu, kan tidak akan berbahaya. Keberadaan rokok ini bagus, karena dapat menambah pemasukan negara."

Mencermati respons tersebut, peneliti memperoleh gambaran bahwa siswa benar-benar mampu memilih argumentasi dan data-data yang tepat, tentu dalam memilih argumentasi dan data-data siswa harus berpikir, tidak memilih secara sembarangan. Hal tersebut senada dengan pandangan Dhajiri (1985: 133) bahwa manfaat metode problem solving adalah mengembangkan keterampilan berpikir seseorang. Artinya, dengan menggunakan metode problem solving dalam debat, keterampilan berpikir siswa menjadi berkembang.

$$
\text { Pada kegiatan akhir }
$$

pembelajaran, siswa telah memperoleh gambaran mengenai penggunaan metode problem solving dalam pembelajaran debat, yaitu cara-cara memberikan argumentasi mengenai permasalahan yang sedang dihadapi, menyelesaikan permasalahan tersebut, sehingga siswa mampu menyampaikan alternatif masalah dan kesimpulan dengan baik. Hal tersebut terbukti ketika siswa yang bernama Kadek Suci Lestari menyampaikan alternatif mengenai permasalahan penerapan E-Learning di sekolah. Berikut 
kutipan alternatif yang disampaikan oleh siswa.

Suci (kontra 3): "Tim kontra 3 memberikan alternatif sebagai berikut. Dari segi fasilitas sekolah, jika sudah siap menerapkan $E$ Learning semua sekolah harus menyediakan akses internet untuk siswa. Meskipun lokasi sekolah berada di pelosok desa, akses internet harus tetap ada. Selain itu guru juga harus lebih tegas kepada siswa. Ketika guru menjelaskan,

siswa harus dilarang keras memegang HP agar konsentrasi siswa tidak terganggu. Ya itu saja, sekian dan terima kasih."

Berdasarkan kutipan alternatif tersebut, siswa telah memperoleh gambaran mengenai metode problem solving yang digunakan dalam pembelajaran debat. $\mathrm{Hal}$ tersebut terbukti dari pemilihan dan penyampaian alternatif yang dilakukan oleh siswa. Siswa mampu memilih alternatif yang tepat berdasarkan permasalahan yang dihadapi. Siswa mengumpulkan data-data yang digunakan dalam alternatif, kemudian menyampaikan alternatif dengan penuh keyakinan. Artinya, siswa telah memiliki bayangan mengenai metode problem solving itu sendiri. Metode problem solving itu sendiri tidak hanya berguna sebagai pisau pemecah masalah dalam debat, tetapi juga berguna sebagai pisau pemecah masalah dalam kehidupan sehari-hari. Senada dengan hal tersebut, Jonassen (dalam Yaumi, 2012: 82) menyatakan bahwa metode problem solving adalah jenis pembelajaran terpenting yang bisa kita pelajari di sekolah dan di kehidupan nyata. Jadi, jika siswa telah memperoleh gambaran mengenai metode problem solving, tentu siswa akan memperoleh pengalaman positif yang nanti akan digunakan dalam kehidupan seharihari.

Kemudian, respons siswa setelah mengikuti penggunaan metode problem solving dalam pembelajaran debat sebagian besar positif, yakni secara umum penggunaan metode problem solving memberikan pengaruh positif untuk siswa, yakni siswa merasa senang serta tertarik, merasa tertantang mengikuti pembelajaran debat, dan mempermudah siswa dalam memecahkan masalah lain dalam kehidupan sehari-hari. Hal tersebut dapat diperkuat berdasarkan respons yang diberikan oleh siswa yang bernama Kadek Prima Budiadnyana. Prima merasa senang mengikuti pembelajaran debat karena dalam pembelajaran debat tidak hanya belajar tentang menyampaikan argumentasi, tetapi juga belajar mencari alternatif atau solusi atas permasalahan yang sedang dibahas. Itulah penyebab ia menyenangi penggunaan metode problem solving dalam pembelajaran debat. Berikut kutipan respons Prima terkait pembelajaran debat yang telah diikutinya.

Prima: "Ya menyenangkan, Bu. debat tadi beda, Bu. Gak hanya menyampaikan argumentasi tapi juga nyari solusi yang tepat untuk masalah yang dibahas."

Mencermati kutipan respons yang diberikan oleh Prima, metode problem solving yang digunakan oleh guru bahasa Indonesia mampu menciptakan suasana belajar yang berbeda. Dalam hal ini, terbukti guru terampil dalam mengelola kelas, sehingga mampu berinovasi, menggunakan metode yang tidak monoton. Senada dengan hal itu, Sunhadi (dalam Jurnal Konsep Manajemen Kelas dan Implikasinya dalam Pembelajaran, 2014:31) 
menyatakan bahwa keterampilan mengelola kelas merupakan salah keterampilan dasar mengajar yang bertujuan untuk mewujudkan dan mempertahankan suasana pembelajaran yang optimal, artinya kemampuan ini erat hubungannya dengan kemampuan profesional guru untuk menciptakan kondisi yang menguntungkan, menyenangkan peserta didik, dan menciptakan disiplin belajar secara sehat. Dengan demikian, kemampuan profesional guru dapat dilihat dari cara guru memilih metode pembelajaran yang sesuai, sehingga pembelajaran menjadi menyenangkan bagi siswa.

Selain itu, penggunaan metode problem solving dalam pembelajaran debat juga dapat menantang siswa belajar. Seperti respons yang diberikan oleh Komang Surini yang menyatakan bahwa dirinya merasa tertantang mengikuti pembelajaran debat, karena selain menyampaikan argumentasi, siswa dituntut untuk mencari alternatif yang tepat agar masalah yang dihadapi dapat terselesaikan. Berikut kutipan respons yang diberikan oleh Komang Surini.

Surini: "Ya saya dan temen-temen tadi tertantang. Karna kita kan harus nyampein argumen yang kuat. Di akhir juga kita kan harus nyelesein masalah itu. Jadi kita seperti bener-bener terlibat dalam masalah penerapan E-Learning itu, Bu."

Berdasarkan respons tersebut, penggunaan metode problem solving dalam pembelajaran debat menimbulkan tantangan bagi siswa. Jika siswa merasa tertantang, tentu motivasi belajar siswa akan tumbuh karena motivasi menumbuhkan gairah. Senada dengan hal tersebut, Handhika (dalam Jurnal Efektivitas Media Pembelajaran IM3 Ditinjau
Dari Motivasi Belajar, 2012: 2) mengatakan bahwa motivasi dapat menumbuhkan gairah, merasa senang dan semangat untuk belajar. Dengan demikian, siswa yang memiliki motivasi kuat, akan mempunyai banyak energi untuk melakukan kegiatan belajar. Rasa tertantang tersebut merupakan sumber motivasi.

Penggunaan metode problem solving juga mempermudah siswa dalam memecahkan masalah lain dalam kehidupan sehari-hari. Setelah mengikuti pembelajaran debat, siswa telah memperoleh pengalaman memecahkan masalah, sehingga siswa akan memiliki bekal yang digunakan untuk mempermudah dalam memecahkan masalah dalam kehidupan seharihari. Hal tersebut terbukti berdasarkan kutipan respons yang disampaikan oleh Kadek Suci Lestari. Berikut adalah kutipan responnya.

Suci: "Menurut saya ya, Bu. Karena tadi saya udah dilatih berpikir, Bu. Gimana cari alternatif masalah. Jadi nanti saya bisa menerapkan di luar sekolah, Bu."

Peneliti

mendapatkan gambaran bahwa metode problem solving dalam pembelajaran debat akan memengaruhi kemampuan siswa menghadapi permasalahan di luar lingkungan sekolah. Dengan berbekal pengalaman mengikuti penggunaan metode problem solving dalam pembelajaran debat, siswa akan lebih mudah menghadapi dan menyelesaikan masalah yang dihadapi. Hal tersebut sesuai dengan manfaat metode problem solving untuk siswa. Sejalan dengan hal itu, Dhajiri (1985: 133) menyatakan bahwa manfaat metode problem solving adalah mengembangkan kemampuan 
berpikir para siswa, metode problem solving dapat menambah pengetahuan siswa, karena siswa dituntut dapat mengidentifikasi masalah dan mencari alternatif masalah yang dihadapi.

Yang terakhir adalah tentang kendala guru dalam menggunakan metode problem solving pada pembelajaran debat ada dua, yaitu dari segi siswa dan fasilitas sekolah. Berdasarkan hasil wawancara peneliti dengan guru Bahasa Indonesia kelas $X$ yang bernama Ketut Darmayani Bukian S.Pd, guru menyampaikan bahwa dari segi siswa sejumlah dua orang siswa tidak terbiasa berpikir secara ilmiah dan rasional, serta tidak terbiasa berbicara di depan umum. Hal tersebut disebabkan oleh siswa itu sendiri yang kurang berlatih berpikir secara ilmiah dalam kegiatan belajar, kurang berlatih berbicara di depan umum, dan kurang berlatih membaca baik di sekolah maupun di luar sekolah. Berikut kutipan jawaban guru.

Ibu Bukian: "Ada. Dari segi siswa, ada dua siswa memiliki keterbatasan saat praktik debat, mereka tidak terbiasa berbicara di depan umum dan tidak terbiasa berpikir secara ilmiah, sehingga mereka masih mengira-ngira dan ragu-ragu mengenai argumentasi yang disampaikan, grogi dan terbata-bata ketika berbicara atau mengeluarkan pendapat. Hal itu karena siswa tersebut kurang melatih keterampilan berbicara dan berpikirnya, bisa juga karena kurang membaca. Tapi sebagian besar siswa sudah mampu berpikir secara ilmiah dan mampu berbicara di depan umum, sehingga mereka bisa menyampaikan argumentasi dan alternatif dengan jelas dan meyakinkan.
Berdasarkan jawaban yang diberikan oleh guru, sebagaian besar siswa telah mampu mengikuti penggunaan metode problem solving dalam pembelajaran debat dengan baik. Hal tersebut terbukti berdasarkan hasil pembelajaran debat yang telah berlangsung, sebagian besar siswa mampu menyampaikan argumentasi dan alternatif secara jelas dan meyakinkan pendengar. Namun, sebagian kecil siswa kurang mampu mengikuti pembelajaran debat dengan baik. Pada intinya, kendala yang bersumber dari siswa karena kurangnya antusias siswa ketika mengikuti kegiatan belajar dan keterbatasan kemampuan siswa. Hal itu senada dengan pandangan Hadisoeparto (2003: 117) bahwa kendala yang disebabkan oleh siswa bisa terjadi apabila dalam proses belajar mengajar siswa tidak berantusias dan merasa kurang termotivasi mengikuti pembelajaran yang dilaksanakan oleh guru. Siswa yang kurang mampu mengikuti kegiatan belajar dengan maksimal, akan menghambat tujuan pembelajaran. Dengan demikian, pada pembelajaran selanjutnya terutama dalam pembelajaran debat, guru harus lebih intens membimbing siswa yang memiliki kemampuan terbatas, agar seluruh siswa memiliki motivasi belajar yang tinggi.

Kendala yang lain yaitu dari segi fasilitas sekolah. Fasilitas sekolah yang kurang memadai menjadi kendala dalam pembelajaran debat, seperti kurangnya LCD dan buku-buku pelajaran. Berikut kutipan jawaban yang disampaikan oleh guru.

Ibu Bukian: "Ada. Di sini kekurangan LCD. Oleh karena itu, saya tidak bisa menampilkan power point, tidak bisa menampilkan video debat yang 
baik agar tidak terjadi debat kusir. Jadi, saya hanya menyampaikan inti-inti pelajaran, kemudian siswa yang aktif menggali informasi. Selain itu juga jumlah buku paket yang terbatas, jadi siswa tidak bisa membawa buku paket sendiri-sendiri, seluruh siswa tidak bisa jadinya di rumah membaca materi debat pada buku, harus pinjam pada teman yang lain."

Kurangnya LCD menyebabkan guru tidak bisa menyampaikan contoh debat secara intens kepada siswa, maka guru harus menyampaikan secara lisan pokokpokok pembelajaran. Apabila ada LCD, pembelajaran akan lebih praktis dengan power point dan video debat. Selain itu, keterbatasan buku-buku pelajaran yang disediakan di sekolah juga menjadi kendala kegiatan belajar. Hal itu sejalan dengan pandangan Anurrahman (2009: 188) bahwa sarana dan prasarana pembelajaran merupakan faktor yang turut memberikan pengaruh terhadap hasil belajar siswa. Apabila jumlah LCD dan buku-buku pelajaran terbatas, hal itu akan berpengaruh terhadap hasil belajar siswa. LCD merupakan jenis media yang dapat digunakan dalam kegiatan belajar. Dengan adanya media pembelajaran, guru dapat menciptakan berbagai situasi kelas. media pembelajaran dapat menciptakan iklim emosional yang sehat di antara peserta didik. Bahkan, media pembelajaran dapat membantu guru membawa dunia luar ke dalam kelas. Selain itu, keterbatasan buku pelajaran juga berpengaruh terhadap kegiatan belajar. Buku teks atau buku pelajaran merupakan salah satu sumber belajar dan bahan ajar yang banyak digunakan dalam pembelajaran. Apabila jumlah buku pelajaran terbatas, maka akan menghambat tujuan pembelajaran yang hendak dicapai. Menyikapi hal tersebut, sebaiknya pihak sekolah lebih memperhatikan fasilitas yang dapat membantu guru dan siswa dalam kegiatan belajar mengajar. Kepala sekolah hendaknya mengusahakan agar jumlah sarana dan prasarana pembelajaran memadai, guna mencapai tujuan pembelajaran yang maksimal, seperti jumlah LCD dan buku pelajaran siswa (buku paket dan buku LKS).

\section{SIMPULAN DAN SARAN}

Ada beberapa simpulan yang dapat diambil berdasarkan hasil dan pembahasan penelitian yaitu, (1) penggunaan metode problem solving telah berlangsung efektif dan kondusif, serta memenuhi prosedur. Pada awal pembelajaran guru telah mampu menggiring siswa mengikuti pembelajaran debat dengan baik, sehingga siswa mengikuti pembelajaran debat dengan antusias dan suasana kelas menjadi kondusif. Pada inti pembelajaran siswa telah mampu mengikuti pembelajaran debat dengan maksimal, berdiskusi dengan baik, saling berargumentasi dengan tertib, dan guru berperan aktif ketika menyatukan persepsi siswa untuk memperoleh alternatif masalah, sehingga tidak terjadi debat kusir. Pada akhir pembelajaran siswa telah memperoleh gambaran mengenai penggunaan metode problem solving dalam pembelajaran debat, yaitu cara-cara memberikan argumentasi mengenai permasalahan yang sedang dihadapi, menyelesaikan permasalahan tersebut, sehingga siswa mampu menyampaikan alternatif masalah dan kesimpulan 
dengan baik. (2) Secara umum siswa memberikan respons positif, yaitu siswa merasa senang, tertantang, tertarik, dan mempermudah siswa dalam memecahkan masalah lain dalam kehidupan sehari-hari. Hal tersebut disebabkan oleh penggunaan metode problem solving pada pembelajaran debat dapat melatih keterampilan berpikir siswa dan memberikan pengalaman dalam menyelesaikan masalah. (3) Kendala guru dalam menggunakan metode problem solving pada pembelajaran debat ada dua, yaitu dari segi siswa dan fasilitas sekolah. Dari segi siswa, sebagian kecil siswa kurang atau belum memahami masalah yang diperdebatkan, kurangnya minat membaca dan pengalaman siswa. Dari segi fasilitas sekolah, ketersediaan LCD dan buku pelajaran yang terbatas menyebabkan guru menemui kendala pada penggunaan metode problem solving dalam pembelajaran debat.

Berdasarkan pemaparan mengenai hasil penelitian dan simpulan, ada tiga saran yang dapat disampaikan dalam penelitian ini.

Pertama, disarankan kepada guru Bahasa Indonesia tersebut agar mempertahankan keefektifan pembelajaran debat bahkan harus berupaya meningkatkan keefektifan penggunaan metode problem solving dalam pembelajaran debat. Disarankan juga kepada guru Bahasa Indonesia yang lain agar mencoba menggunakan metode problem solving dalam kegiatan belajar mengajar di kelas, karena metode problem solving bermanfaat untuk melatih keterampilan berpikir dan berbicara siswa. Kedua, disarankan kepada guru agar lebih memotivasi siswa yang kurang aktif dan miliki keterbatasan. Ketiga, disarankan kepada siswa agar lebih giat belajar dan berlatih di sekolah maupun di luar sekolah, serta disarankan kepada pihak sekolah agar lebih meningkatkan fasilitas pembelajaran guna tercapainya tujuan pembelajaran.

\section{DAFTAR PUSTAKA}

Aunurrahman. 2009. Belajar dan Pembelajaran. Bandung: Alfabeta.

Dhajiri, Ahmad Kosasih. 1985. Strategi Pengajaran Afektif, Nilai, Moral, VCT, dan Games dalam VTC. Bandung: Jurusan PMPKn IKIP.

Hadisoeparto, A. 2003. Kesulitan Belajar Mengajar. Jakarta: Bina Aksara.

Handhika, J. 2012. Efektivitas Media Pembelajaran IM3 Ditinjau Dari Motivasi Belajar. 24 Maret 2018.

https://www.google.com/url?sa $=\mathrm{t} \& \mathrm{rct}=\mathrm{i} \& \mathrm{q}=\& \mathrm{esrc}=\mathrm{s} \&$ source $=$ web\&cd=6\&ved=0ahUKEwi z9mX07LaAhUDul8KHfGBC cQFghEMAU\&url=https $\% 3 A$ 2F\%2Fmedia.neliti.com\% Fmedia\%2Fpublications\%2F1 22973-ID-efektivitas-mediapembelajaran-im3 ditin.pdf\&usg=AOvVaw298RX ZmJ4rYKSSTHIn9nOW

Lestariani, Ni Putu Ayu Nita. 2014. Kesantunan Bahasa Siswa Kelas X SMA Negeri 1 Selemadeg dalam Debat pada Pembelajaran Berbicara. Skripsi (tidak diterbitkan). Singaraja: Universitas Pendidikan Ganesha.

Martha, I Nengah. 2009. Pengantar Kependidikan. Singaraja: Undiksha.

Sujarweni, Wiratna. 2014. Metodologi Penelitian. 
Yogyakarta:

PUSTAKABARUPRESS.

Sunhadi. 2014. Konsep Manajemen

Kelas dan Implikasinya dalam Pembelajaran. 24 Maret 2018.

https://www.google.com/url?sa $=$ t $\&$ rct $=\mathrm{i} \& \mathrm{q}=\&$ esrc $=\mathrm{s} \&$ source $=$ web\&cd $=4 \&$ ved $=0$ ahUKEwiV3f XQsILaAhXDipQKHUFEBaoQ Fgg8MAM\&url=https\%3A\%2F $\% 2 F m e d i a . n e l i t i . c o m \% 2 F m e d i$ a\%2Fpublications\%2F104713ID-konsep-manajemen-kelasdan implikasinya. $p d f \& u s g=A O v V a$ w1pfgnV 2zwmLcFLeeN1B1U Supriatna, Eka, dan Muhammad Arif Wahyupurnomo. Keterampilan Guru dalam Membuka dan Menutup Pelajaran Pendidikan Jasmani Olahraga dan Kesehatan di SMAN se-Kota Pontianak. 11 Maret 2018. https://www.google.com/url?sa $=$ t $\&$ rct $=\mathrm{j} \& \mathrm{q}=\&$ esrc $=$ s\&source $=$ web\&cd=3\&ved=0ahUKEw oveH5zbLaAhULYo8KHX0SC bYQFgg7MAI\&url=https $\% 3 A \%$ 2F\%2Fjournal.uny.ac.id\%

Findex.php\%2Fjpji\%2Farticle \%2FviewFile\%2F8173\%2F684 4\&usg=AOvVaw2bNFyqzyl bQEQJ6EPfTOh

Tarigan, H.G. 2008. Berbicara sebagai Suatu Keterampilan Berbahasa. Bandung: Angkasa.

Wendra, I Wayan. 2015. Profesi Kependidikan. Singaraja: Universitas Pendidikan Ganesha.

Yaumi, Muhamad. 2012.

Pembelajaran Berbasis Multiple Intellgences. Jakarta: Dian Rakyat. 